\title{
Mammography: influence of departmental practice and women's characteristics on patient satisfaction: comparison of six departments in Norway
}

\author{
Kirsti Løken, Siri Steine, Even Lærum
}

\begin{abstract}
Objective-To investigate how departmental practice and women's characteristics are related to low patient satisfaction with mammography.

Design-Survey of patients by means of self administered questionnaires before and after mammography.

Patients-488 women (89\% of those invited), aged 23-86 years, at six departments.

Main outcome measures-Low level of satisfaction measured on psychometric scales of physical pain, psychological distress, staff punctuality and technical skills, information provided, and physical surroundings.

Results-Satisfaction varied by department on the scales for pain, punctuality, information, and surroundings. After adjustment for women's characteristics an attributable risk of negative outcome by department was identified on the scales for pain, distress, punctuality, information, and surroundings. Adjusted odds ratio (ORs) ranged from 0.3 (95\% confidence interval $(95 \% \mathrm{CI}) 1.2$ to 6.0$)$ on the pain scale, to 6.0 (2.9 to 12.3$)$ on the punctuality scale. After adjustment for confounding variables, higher risk of dissatisfaction was associated with age $<50$, nervousness about mammography, expected pain, lack of knowledge about mammography, and distrust in mammography (adjusted OR $(95 \% \mathrm{CI})$ ranged from $1.6(1.0$ to 2.7$)$ to $3.7(2.0$ to 7.3$)$ ).

Conclusion-Departmental practices differed for breast compression, information, punctuality, and facilities and were associated with a low level of satisfaction irrespective of patient characteristics. Women's lack of knowledge about mammography and distrust in the procedure were confirmed as risk factors for dissatisfaction. All these factors might be helped by training the staff, improving facilities, and informing the women. (Quality in Health Care 1998;7:136-141)
\end{abstract}

Keywords: patient satisfaction; quality of care; mammography

\section{Introduction}

The efficacy of breast screening programmes depends on women's participation and reattendance rates, ${ }^{1-4}$ which are positively related to user acceptability, and many authors have argued that patient satisfaction must be tested and surveyed alongside other criteria when assessing the performance of mammography services. ${ }^{5-8}$

However, accepted standards for quality of mammography do not include acceptability, but refer exclusively to the technical and interpretative aspects of the examination. ${ }^{9-11}$ This may be partially explained by the fact that assessing patient satisfaction is not straightforward..$^{12}$ One approach is to identify issues that women take into account when assessing mammography, and then develop an outcome measure that covers these topics. ${ }^{6} 1415$

Women's evaluations of a mammography service have been commonly related to the following six aspects of the procedure; pain, discomfort, or embarrassment associated with the breast compression, the amount of information given to them, waiting time associated with the procedure, quality of the facilities, and the technician's skills. ${ }^{16-21}$ These are all aspects of care that can indicate substantial scope for reducing non-attendance by improving the way mammography is provided.

We have used these six aspects of acceptability to develop the multidimensional, psychometrically evaluated mammography questionnaire. $^{22}$ The questionnaire (appendix) could be completed by the women immediately after the examination and before leaving the department.

Acceptability of mammography is influended not only by a woman's experience of the procedure but also by her own personal characteristics, expectations, and attitudes. Thus, when monitoring satisfaction and looking for ways to improve care, the confounding potential of these personal factors must be clarified. ${ }^{23} 24$

One way to evaluate the mammography services is to compare their practices. ${ }^{25}$ This makes it possible to identify the extent of variations in practice which cannot be explained by variations in the type of women examined.

The first aim of the study was to identify the association between mammography practice in six departments as measured by low level of patient satisfaction measured as pain, discomfort, provision of information, punctuality, surroundings, and technical skills in aspects of care. Secondly, as a women's attitudes and expectations may also influence satisfaction, we wanted to identify how these personal factors were related to a low level of satisfaction. 


\section{Method}

MAMMOGRAPHY IN NORWAY

General population based breast screening programmes have not been introduced in Norway (box 1), and the women included in this survey were referred by general practitioners. Owing to a complex system of reimbursement, the physicians' referrals have seldom separated health screening from clinical mammography, and both categories were thus included. To separate health screening from the diagnostic procedures the patients were asked about subjective breast symptoms in the questionnaire before the examination.

- General population based screening programmes have not been introduced

- Mammography is widely used in some areas as health screening

- There is a complex reimbursement system for mammography

- Physicians' referrals do not always discriminate between diagnostic examinations and health screening procedures

Box 1 Mammography in Norway.

THE PROCEDURE

The mammograms were obtained in accordance with the current clinical practice in each department. Norwegian guidelines recommend forced compression limited to $18 \mathrm{~kg}$. ${ }^{26}$ The women were not informed about the results of the examination before leaving the department.

STUDY DESIGN

Six mammography departments in Norway were included in this cross sectional prospective study. Data were collected from two self administered questionnaires; one before mammography (box 2) and the 27 item mammography questionnaire afterwards.

How do you think you will experience the examination? Take a standpoint on the following assertions.

I have been satisfactorily informed about what will be done to my breasts at the examination.

I think the examination will be painful.

Just at this moment I do not dread the examination.

I think the examination will be unpleasant.

I think this examination is reliable.

Box 2 Women's experience, expectations, and attitudes. Items from the questionnaire before mammography.

DEPARTMENTAL CHARACTERISTICS

One of our aims was to compare satisfaction with mammography at six different departments. Accordingly, the departments were not chosen at random, but carefully selected to cover a broad range of services. ${ }^{27}$ Four departments were localised in urban and two in rural districts. Two university hospitals and one regional hospital were public, and three were private outpatient clinics. All departments had one or more dedicated mammography $x$ ray units, all had provided mammography for years, and in most departments the mammography technicians were women. Type of equipment and the technician's sex were not recorded. The comfort of waiting areas and quality of the examination rooms differed between departments as evaluated by one of us.

\section{PARTICIPANTS}

After arriving at the department the women were invited by a receptionist to participate in the study. The receptionist distributed the two questionnaires with a covering letter from the study group about the patients' rights and the purpose of the study. Written consent was given by all women approached. At each department the sampling was consecutive until at least 50 patients had completed both questionnaires.

\section{BEFORE MAMMOGRAPHY: A SHORT}

QUESTIONNAIRE

The following sociodemographic variables and items of women's characteristics were recorded from a brief questionnaire before the procedure; age, shared household, years of education, occupational status, subjective breast symptoms, and previous mammography experience.

Questions pertaining to the women's attitudes - such as knowledge about the procedure, nervousness about mammography, expected pain, and trust in the diagnostic value of mammography - were measured on a Likert five point scale (strongly agree, agree, neutral, disagree, strongly disagree).

\section{AFTER MAMMOGRAPHY: THE MAMMOGRAPHY} QUESTIONNAIRE

The development of the 27 item mammography questionnaire has been described elsewhere. Factor analysis of the 27 item version had resulted in a condensed 19 item version containing eight scales. ${ }^{28}$ Two scales for general satisfaction indicated no specific guidelines for service modifications and were deleted. The remaining six scales, comprising 14 items, were used as outcome measures in the present study to identify low level of satisfaction in six different mammography departments associated with six different aspects of practice:

- Pain

- Discomfort

- Provision of information

- Punctuality

- Surroundings

- Technical skills in aspects of care.

Response scores in each scale were transformed with a potential range of $0-100$, in which 100 represents the best possible experience.

\section{ANALYSES}

Mammography screening guidelines apply to women over 50 years of age, and age and marital status (cohabitation) have been used to assess acceptability of mammography. ${ }^{29}{ }^{30}$ The patients' characteristics were dichotomised as follows: age, $<50$ or $\geqslant 50$; shared household, yes or no; education, $<13$ or $\geqslant 13$ years; occu- 
Table 1 Characteristics of the 488 women

\begin{tabular}{|c|c|c|c|c|c|c|}
\hline \multirow[b]{2}{*}{ Women's characteristics } & \multicolumn{6}{|c|}{ Departments (n (\%)) } \\
\hline & $A$ & $B$ & $C$ & $D$ & $E$ & $F$ \\
\hline \multicolumn{7}{|l|}{ Age (y): } \\
\hline$<50$ & $71(55.9)$ & $43(44.3)$ & $25(50.0)$ & $50(68.5)$ & $51(63.0)$ & $32(53.3)$ \\
\hline$\geqslant 50$ & $56(44.1)$ & $54(55.7)$ & $25(50.0)$ & $23(31.5)$ & $30(37.0)$ & $28(46.7)$ \\
\hline \multicolumn{7}{|l|}{ Education (y): } \\
\hline$<13$ & $32(25.2)$ & $45(46.9)$ & $18(36.7)$ & $44(60.3)$ & $51(63.7)$ & $13(22.0)$ \\
\hline$\geqslant 13$ & $95(74.8)$ & $51(53.1)$ & $31(63.3)$ & $29(39.7)$ & $29(36.3)$ & $46(78.0)$ \\
\hline \multicolumn{7}{|l|}{ Occupational status: } \\
\hline Low & $23(18.3)$ & $45(47.4)$ & $13(26.5)$ & $31(44.3)$ & $36(46.2)$ & $17(30.9)$ \\
\hline High & $103(81.7)$ & $50(52.6)$ & $36(73.5)$ & $39(55.7)$ & $42(53.8)$ & $38(69.1)$ \\
\hline \multicolumn{7}{|l|}{ Shared household: } \\
\hline Yes & $97(76.4)$ & $72(74.2)$ & $35(70)$ & $60(82.2)$ & $59(73.8)$ & $52(86.7)$ \\
\hline No & $27(21.8)$ & $23(23.7)$ & $14(28)$ & $11(15.1)$ & $21(25.9)$ & $6(10.0)$ \\
\hline \multicolumn{7}{|c|}{ Previous mammography: } \\
\hline Yes & $74(58.7)$ & $63(65.6)$ & $27(54.0)$ & $45(61.6)$ & $65(83.3)$ & $25(41.7)$ \\
\hline No & $52(41.3)$ & $33(34.4)$ & $23(46.0)$ & $28(38.4)$ & $13(16.7)$ & $35(58.3)$ \\
\hline \multicolumn{7}{|l|}{ Breast symptoms: } \\
\hline Yes & $40(31.7)$ & $24(25.5)$ & $3(27.1)$ & $42(59.2)$ & $50(63.3)$ & $27(48.2)$ \\
\hline No & $86(68.3)$ & $70(74.5)$ & $35(72.9)$ & $29(40.8)$ & $29(36.7)$ & $29(51.8)$ \\
\hline \multicolumn{7}{|l|}{ Sufficient knowledge: } \\
\hline Yes & $87(68.5)$ & $68(70.1)$ & $33(66.0)$ & $48(65.8)$ & $64(79.0)$ & $31(51.7)$ \\
\hline No & $40(31.5)$ & $29(29.9)$ & $17(34.0)$ & $25(34.2)$ & $17(21.0)$ & $29(48.3)$ \\
\hline \multicolumn{7}{|c|}{ Nervousness about mammography: } \\
\hline Yes & $33(26.4)$ & $24(25.3)$ & $17(34.0)$ & $18(24.7)$ & $26(32.9)$ & $28(46.7)$ \\
\hline No & $92(73.6)$ & $71(74.7)$ & $33(66.0)$ & $55(75.3)$ & $53(67.1)$ & $32(53.3)$ \\
\hline \multicolumn{7}{|l|}{ Expected pain: } \\
\hline Yes & $71(56.8)$ & $43(45.3)$ & $32(64.0)$ & $26(35.6)$ & $45(57.0)$ & $39(65.0)$ \\
\hline No & $54(43.2)$ & $52(54.7)$ & $18(36.0)$ & $47(64.4)$ & $34(43.0)$ & $21(35.0)$ \\
\hline \multicolumn{7}{|c|}{ Distrust in mammography: } \\
\hline Yes & $9(7.2)$ & $12(12.5)$ & $9(18.4)$ & $13(18.8)$ & $10(12.5)$ & $10(17.5)$ \\
\hline No & $116(92.8)$ & $84(87.5)$ & $40(81.6)$ & $56(81.2)$ & $70(87.5)$ & $47(82.5)$ \\
\hline
\end{tabular}

Because of missing values, the numbers do not always add up to $100 \%$ of 488 patients.

pational class, low or high; breast symptoms, yes or no; previous examination, yes or no.

There were several categories of the variables for expectation and attitude-for example, strongly agree or agree. Descriptive statistics were produced to examine the patients' characteristics in each setting.

We assumed that low satisfaction would be linked to clinically important differences associated with either or both departments or patients' characteristics. To estimate the probability of negative experience of mammography the outcome scales were dichotomised. As $76 \%-84 \%$ levels of satisfaction have been found in most other studies, this supported placing the cut off between satisfied and less satisfied patients at the lowest quartile of each scale. ${ }^{31}{ }^{32}$ The scales were skewed with mean scores far above the median, which also made it more appropriate to use logistic models rather than linear ones. ${ }^{33}$

Logistic regression analysis was used to calculate the associations between each independent variable and low level of satisfaction. Multivariate logistic regression analyses were performed to identify factors independently associated with low satisfaction, and department A (that had the most participants) was chosen as the reference. The variables included were those found to be significant in the univariate analysis. Criteria for entry $(p=0.05)$ of all variables included in table 1 were based on the likelihood test.

ETHICS

The study was approved by the Norwegian Data Inspectorate and the Regional Medical Ethics Committee.

\section{Results}

CHARACTERISTICS OF PATIENTS

Of the 550 women included, 488 (89\%) completed both questionnaires. Ages ranged from 23 to 86 years, mean 50 (SD 11) years. The distribution of women in the departments according to patient characteristics is shown in table 1 . Considerable variations were detected, and the following factors were therefore controlled for: age, shared household, level of education, occupational status, previous mammography experience, breast symptoms, knowledge about mammography, nervousness about mammography, expected pain, and confidence in mammography.

\section{VARIATIONS BETWEEN DEPARTMENTS}

In the bivariate analysis one or more departments were significantly associated with low satisfaction measured as pain, punctuality, information, and surroundings (table 2). The significance of the variables changed when they were put together in a multivariate model (table 3). After controlling for confounding factors, higher risk of low satisfaction on the distress, punctuality, and information scales was associated with one or more departments compared with department A (odds ratio (OR) ranged from 2.1 (95\% confidence interval ( $95 \% \mathrm{CI}) 1.1$ to 4.2 ) to 5.4 (2.8 to 10.8$)$ ). Thus, when compared with department A, undergoing mammography at department B entailed increased risk of distress, mammography at departments B, D, E, and F entailed increased risk of experiencing lack of punctuality, whereas undergoing mammography at departments B, C, and D entailed higher risk of dissatisfaction with the information received. 
Table 2 Bivariate analysis in terms of $O R$ and the $p$ values of low level of patient satisfaction for six variables of the mammography questionnaire MGQ

\begin{tabular}{|c|c|c|c|c|c|c|c|}
\hline & & Pain & Distress & Punctuality & Information & Surroundings & Technical skills \\
\hline Variables & $\begin{array}{l}\text { Women } \\
n(\%)\end{array}$ & $\begin{array}{l}\text { Unadjusted OR } \\
(95 \% \mathrm{CI})\end{array}$ & $\begin{array}{l}\text { Unadjusted OR } \\
(95 \% \mathrm{CI})\end{array}$ & $\begin{array}{l}\text { Unadjusted } O R \\
(95 \% \mathrm{CI})\end{array}$ & $\begin{array}{l}\text { Unadjusted } O R \\
(95 \% \mathrm{CI})\end{array}$ & $\begin{array}{l}\text { Unadjusted } O R \\
(95 \% \mathrm{CI})\end{array}$ & $\begin{array}{l}\text { Unadjusted } O R \\
(95 \% \mathrm{CI})\end{array}$ \\
\hline \multicolumn{8}{|c|}{ Department: } \\
\hline A & $127(26)$ & 1 & 1 & 1 & 1 & 1 & 1 \\
\hline B & $97(20)$ & $0.6(0.4$ to 1.2$)$ & $1.6(0.9$ to 3.0$)$ & $2.6(1.5 \text { to } 4.6)^{\star \star \star}$ & $2.6(1.4 \text { to } 5.0)^{\star \star}$ & $0.3(0.2 \text { to } 0.8)^{\star}$ & $2.1(1.0$ to 4.8$)$ \\
\hline $\mathrm{C}$ & $50(10)$ & $1.1(0.6$ to 2.3$)$ & $1.5(0.8$ to 3.3$)$ & $1.2(0.6$ to 2.4$)$ & $2.5(1.2 \text { to } 5.4)^{\star}$ & $0.6(0.3$ to 1.5$)$ & 1.5 (0.6 to 4.2$)$ \\
\hline $\mathrm{D}$ & $73(15)$ & $0.7(0.4$ to 1.3$)$ & $1.2(0.6$ to 2.4$)$ & $1.9(1.1 \text { to } 3.5)^{\star}$ & $2.4(1.2 \text { to } 4.9)^{\star}$ & $2.0(1.1 \text { to } 3.8)^{\star}$ & 2.080 .9 to 4.8$)$ \\
\hline $\mathrm{E}$ & $81(17)$ & $1.8(1.0 \text { to } 3.2)^{\star}$ & $1.4(0.8$ to 2.8$)$ & $4.5(2.5 \text { to } 8.5)^{\star \star \star}$ & $1.6(0.8$ to 3.3$)$ & $1.1(0.6$ to 2.2$)$ & $1.6(0.7$ to 3.9$)$ \\
\hline $\mathrm{F}$ & $60(12)$ & $0.8(0.4$ to 1.6$)$ & $1.1(0.5$ to 2.3$)$ & $3.2(1.7 \text { to } 6.2)^{\star \star \star}$ & $1.6(0.8$ to 3.5$)$ & $1.8(1.0$ to 3.6$)$ & $0.8(0.4$ to 3.4$)$ \\
\hline \multicolumn{8}{|l|}{ Age $(y)$ : } \\
\hline$<50$ & $272(56)$ & $1.3(1.0$ to 2.0$)$ & $2.6(1.7 \text { to } 4.1)^{\star \star \star \star}$ & $1.1(0.7$ to 1.7$)$ & $1.7(1.2 \text { to } 2.7)^{\star \star}$ & $2.8(1.8 \text { to } 4.4)^{\star \star \star}$ & $2.8(1.6 \text { to } 5.2)^{\star \star \star}$ \\
\hline$\geqslant 50$ & $216(44)$ & 1 & 1 & 1 & 1 & 1 & 1 \\
\hline \multicolumn{8}{|c|}{ Level of education (y): } \\
\hline$<13$ & $281(58)$ & $1.0(0.9$ to 1.3$)$ & $1.6(1.2 \text { to } 2.5)^{\star \star}$ & $1.4(1.0$ to 2.3$)$ & $0.9(0.7$ to 1.7$)$ & $0.6(0.4 \text { to } 1.0)^{\star}$ & $0.4(0.3 \text { to } 0.7)^{\star \star}$ \\
\hline$\geqslant 13$ & $203(42)$ & 1 & 1 & 1 & 1 & 1 & 1 \\
\hline \multicolumn{8}{|c|}{ Occupational status: } \\
\hline Low & $308(63)$ & $1.2(0.8$ to 1.8$)$ & $1.3(0.9$ to 2.0$)$ & $1.2(0.8$ to 2.0$)$ & $0.7(0.5$ to 1.1$)$ & $0.7(0.5$ to 1.1$)$ & $0.5(0.3 \text { to } 0.9)^{\star}$ \\
\hline High & $165(34)$ & 1 & 1 & 1 & 1 & 1 & 1 \\
\hline \multicolumn{8}{|c|}{ Shared household: } \\
\hline No & $102(21)$ & $0.8(0.4$ to 1.0$)$ & $0.9(0.6$ to 1.6$)$ & $1.2(0.8$ to 2.0$)$ & 0.7 (0.5 to 1.2$)$ & $1.2(0.7$ to 2.0$)$ & $1.1(0.8$ to 1.6$)$ \\
\hline Yes & $375(77)$ & 1 & 1 & 1 & 1 & 1 & 1 \\
\hline \multicolumn{8}{|c|}{ Previous mammography: } \\
\hline Yes & $299(62)$ & $1.2(0.9$ to 1.9$)$ & $1.4(0.9$ to 2.2$)$ & $0.9(0.7$ to 1.4$)$ & $0.6(0.5$ to 1.0$)$ & $0.9(0.8$ to 1.9$)$ & $1.0(0.6$ to 1.9$)$ \\
\hline No & $184(38)$ & 1 & 1 & 1 & 1 & 1 & 1 \\
\hline \multicolumn{8}{|c|}{ Breast symptoms: } \\
\hline Yes & $196(40)$ & $1.9(1.3 \text { to } 2.8)^{\star \star \star}$ & $1.1(1.0$ to 1.5$)$ & $0.9(0.8$ to 1.6$)$ & $0.8(0.6$ to 1.3$)$ & $1.5(1.0$ to 2.4$)$ & $1.2(0.7$ to 2.1$)$ \\
\hline No & $278(57)$ & 1 & 1 & 1 & 1 & 1 & 1 \\
\hline \multicolumn{8}{|c|}{ Sufficient knowledge: } \\
\hline No & $157(32)$ & $1.2(0.8$ to 1.8$)$ & $2.4(1.6 \text { to } 3.7)^{\star \star \star}$ & $1.1(0.6$ to 1.6$)$ & $1.6(1.1 \text { to } 2.5)^{\star \star}$ & $1.6(1.1 \text { to } 2.5)^{\star}$ & $2.0(1.2 \text { to } 3.4)^{\star \star}$ \\
\hline Yes & $331(68)$ & 1 & 1 & 1 & 1 & 1 & 1 \\
\hline \multicolumn{8}{|c|}{ Nervousness about mammography: } \\
\hline Yes & $146(30)$ & $2.8(1.6 \text { to } 3.8)^{\star \star \star}$ & $1.4(1.2 \text { to } 1.7)^{\star \star \star}$ & $1.3(0.8$ to 2.1$)$ & $1.2(0.8$ to 1.9$)$ & $1.0(0.9$ to 1.3$)$ & $1.7(1.0 \text { to } 3.0)^{\star}$ \\
\hline No & $336(69)$ & 1 & 1 & 1 & 1 & 1 & 1 \\
\hline \multicolumn{8}{|c|}{ Expected pain: } \\
\hline Yes & $226(46)$ & $2.3(1.6 \text { to } 3.5)^{\star \star \star}$ & $1.1(1.0$ to 1.3$)$ & $1.1(0.7$ to 1.7$)$ & $0.9(0.8$ to 1.7$)$ & $0.9(0.9$ to 2.0$)$ & $1.1(0.7$ to 2.0$)$ \\
\hline No & $256(53)$ & 1 & 1 & 1 & 1 & 1 & 1 \\
\hline \multicolumn{8}{|c|}{ Distrust in mammography: } \\
\hline Yes & $413(85)$ & $1.1(0.7$ to 2.8$)$ & $1.3(1.1 \text { to } 1.8)^{\star}$ & $1.4(0.8$ to 2.6$)$ & $2.7(1.6 \text { to } 4.7)^{\star \star \star}$ & $3 . .2(1.9 \text { to } 5.6)^{\star \star \star}$ & $2.2(1.2 \text { to } 4.3)^{\star}$ \\
\hline No & $63(13)$ & 1 & 1 & 1 & 1 & 1 & 1 \\
\hline
\end{tabular}

${ }^{\star} \mathrm{p}<0.05,{ }^{\star \star} \mathrm{p}<0.01,{ }^{\star \star \star} \mathrm{p}<0.001$.

Because of missing values for some variables, numbers of patients do not always add up to 488 .

By contrast, on the pain scale and the surroundings scale, the odds of a negative outcome were lower for one or more departments relative to department A (OR ranged from 0.4 ( $95 \%$ CI 1.1 to 4.2 ) to 0.3 (0.1 to 0.8$)$ ). Thus compared with department $\mathrm{A}$, if a woman had a mammogram at department $\mathrm{C}$ or $\mathrm{F}$ she entailed less risk of experiencing a high level of pain, and having a mammogram at department B entailed less risk of low satisfaction with the surroundings.

FACTORS RELATED TO THE WOMEN THEMSELVES Satisfaction varied for women's characteristics on all scales. Mammography experience and living in a shared household were not associated with level of satisfaction. When controlled

Table 3 Multivariate logistic regression analyses of significant factors for risk of low level of patient satisfaction for six variables of the mammography questionnnaire $M G Q$

\begin{tabular}{|c|c|c|c|c|c|c|}
\hline & Pain & Distress & Punctuality & Information & Surroundings & Tecnical skills \\
\hline Variables & $\begin{array}{l}\text { Adjusted OR } \\
(95 \% \mathrm{CI})\end{array}$ & $\begin{array}{l}\text { Adjusted OR } \\
(95 \% \mathrm{CI})\end{array}$ & $\begin{array}{l}\text { Adjusted OR } \\
(95 \% \mathrm{CI})\end{array}$ & $\begin{array}{l}\text { Adjusted OR } \\
(95 \% \mathrm{CI})\end{array}$ & $\begin{array}{l}\text { Adjusted OR } \\
(95 \% \mathrm{CI})\end{array}$ & $\begin{array}{l}\text { Adjusted OR } \\
(95 \% \mathrm{CI})\end{array}$ \\
\hline \multicolumn{7}{|c|}{ Department: } \\
\hline A & 1 & 1 & 1 & 1 & 1 & 1 \\
\hline B & $0.7(0.4$ to 1.4$)$ & $2.1(1.1 \text { to } 4.2)^{\star}$ & $2.7(1.5 \text { to } 5.0)^{\star \star \star}$ & $3.0(1.5 \text { to } 6.2)^{\star \star}$ & $0.3(0.1 \text { to } 0.8)^{\star}$ & $1.5(0.6$ to 3.9$)$ \\
\hline $\mathrm{C}$ & $0.9(0.5$ to 2.0$)$ & $1.6(0.7$ to 3.7$)$ & $1.0(0.5$ to 2.3$)$ & $2.3(1.0 \text { to } 5.5)^{\star}$ & $0.5(0.2$ to 1.4$)$ & $1.1(0.4$ to 3.6$)$ \\
\hline $\mathrm{D}$ & $0.4(0.2 \text { to } 1.0)^{\star}$ & $0.7(0.3$ to 1.7$)$ & $2.2(1.2 \text { to } 4.5)^{\star}$ & $2.7(1.3 \text { to } 6.5)^{\star}$ & $1.7(0.9$ to 3.6$)$ & $1.3(0.5$ to 3.8$)$ \\
\hline $\mathrm{E}$ & $1.2(0.6$ to 2.4$)$ & $1.4(0.7$ to 3.0$)$ & $5.4(2.8 \text { to } 10.8)^{\star \star \star}$ & $1.8(0.8$ to 4.2$)$ & $0.9(0.5$ to 2.0$)$ & $1.1(0.4$ to 3.2$)$ \\
\hline $\mathrm{F}$ & $0.4(0.2 \text { to } 0.9)^{\star}$ & $0.8(0.4$ to 2.1$)$ & $2.7(1.2 \text { to } 4.9)^{\star}$ & $1.3(0.6$ to 3.1$)$ & $1.7(0.8$ to 3.7$)$ & $0.6(0.3$ to 2.7$)$ \\
\hline \multicolumn{7}{|c|}{ Age $<50$ y: } \\
\hline Yes & $1.2(0.8$ to 2.0$)$ & $2.2(1.3 \text { to } 3.7)^{\star \star}$ & $0.8(0.5$ to 1.3$)$ & $1.8(1.1 \text { to } 3.1)^{\star}$ & $2.1(1.3 \text { to } 3.5)^{\star \star}$ & $2.4(1.2 \text { to } 4.9)^{\star}$ \\
\hline No & 1 & 1 & 1 & 1 & 1 & 1 \\
\hline \multicolumn{7}{|c|}{ Sufficient knowledge: } \\
\hline No & $0.9(0.6$ to 1.5$)$ & $2.1(1.3 \text { to } 3.5)^{\star \star}$ & $1.1(0.7$ to 1.8$)$ & $1.9(1.2 \text { to } 3.2)^{\star}$ & $1.6(1.0$ to 2.6$)$ & $1.7(1.0$ to 3.2$)$ \\
\hline Yes & 1 & 1 & 1 & 1 & 1 & 1 \\
\hline \multicolumn{7}{|c|}{ Nervousness about mammography: } \\
\hline Yes & $2.3(1.5 \text { to } 3.9)^{\star \star \star}$ & $1.6(1.0$ to 2.8$)$ & $1.4(0.9$ to 2.3$)$ & $1.1(0.7$ to 2.0$)$ & $0.9(0.6$ to 1.7$)$ & $1.6(0.9$ to 3.2$)$ \\
\hline No & 1 & 1 & 1 & 1 & 1 & 1 \\
\hline \multicolumn{7}{|c|}{ Expected pain: } \\
\hline Yes & $2.1(1.4 \text { to } 3.4)^{\star \star}$ & $1.3(0.8$ to 2.2$)$ & 1. $2(0.8$ to 1.8$)$ & $0.9(0.6$ to 1.6$)$ & $0.9(0.6$ to 1.5$)$ & $1.2(0.7$ to 2.4$)$ \\
\hline No & 1 & 1 & 1 & 1 & 1 & 1 \\
\hline \multicolumn{7}{|c|}{ Distrust in mammography: } \\
\hline Yes & $1.2(0.6$ to 2.3$)$ & $2.0(1.1 \text { to } 3.7)^{\star}$ & $2.2(1.2 \text { to } 4.1)^{\star \star}$ & $2.6(1.5 \text { to } 4.9)^{\star \star \star}$ & $3.4(2.1 \text { to } 5.6)^{\star \star \star}$ & $1.3(0.7$ to 2.9$)$ \\
\hline No & 1 & 1 & 1 & 1 & 1 & 1 \\
\hline
\end{tabular}

${ }^{\star} \mathrm{p}<0.05 ;{ }^{\star \star} \mathrm{p}<0.01 ;{ }^{\star \star \star} \mathrm{p}<0.001$

Level of education, occupational status, and breast symptoms were not significant in the multivariate analysis. 
for other factors, age $<50$, anticipation of pain, lack of knowledge about the examination, nervousness about mammography, and distrust in mammography carried higher risk of low satisfaction with one or more aspects (OR ranged from 1.8 (95\% CI 1.1 to 03.1 ) to 3.4 (2.1 to 5.6) respectively). Breast symptoms, level of education, and occupational status were not identified as significant risk factors.

\section{Discussion}

A key challenge when comparing patient satisfaction with different services and attributing the cause of possible dissatisfaction is to disentangle the effects of case mix from the effects specific to the providers. ${ }^{34}$ After adjusting for patient characteristics, we have shown that women were at significantly higher risk of a negative experience at some departments compared with others. Several factors are known to influence women's satisfaction with mammography, but to our knowledge this study is the first to show that the department is an independent risk factor for low level of satisfaction. This shows a potential for quality improvement that could promote women's use of breast screening.

Corrective actions should be guided by the users' perceptions, ${ }^{35}$ and our results show that comparison of different aspects of departmental practise with a multidimensional questionnaire can provide information about how women accept mammography. The findings support the importance of monitoring satisfaction alongside other criteria when assessing the quality of mammography.

Furthermore, the findings indicate potential for improvement in all the departments-such as making the experience of breast compression less painful and negative, of improving communication skills of staff and interpersonal care in terms of punctuality, or of providing better facilities in the departments. To achieve specific improvements based on these results, information about variations in practice must be given to the departments. An external evaluation can be difficult to accept, ${ }^{36}$ and the findings must be communicated in a nonauthoritative manner. We have not yet reported these results to the departments about the differences between them before the study has been made public. On the other hand, this sort of information may enable the staff to improve quality of care and to improve in a systematic way the interpersonal care connected with mammography. ${ }^{37}$ This alone may promote changes in attitude and improve overall performance. ${ }^{38}$

In radiology departments it may be difficult for patients to evaluate the technical skills of the staff. ${ }^{39}$ The one item scale that measured this aspect showed no difference between departments. This suggest that this scale could perhaps be omitted in the future application of the mammography questionnaire.

Patient satisfaction is liable to individual variation, and not unexpectedly, recorded pain was influenced by anticipated pain and nervousness about mammography. ${ }^{1521}$ Patient's age or previous experience did not predict the level of pain..$^{30}$ Our findings suggest that, regardless of the patient's age and experience, the technician should identify fear of pain, attend to the patient's emotional needs, and help the woman to cope in accordance with relevant guidelines. ${ }^{41-43}$

A negative mammography experience has been associated with women's insecurity and underlying worry. ${ }^{17} 18$ Our study showed that lack of knowledge about the procedure and lack of trust in mammography increased the risk of a negative outcome. To increase women's acceptance the staff should be trained to solicit questions and explain the procedure, keep waiting time to a minimum, and promote an understanding that the procedure is worthwhile. ${ }^{44}{ }^{45}$ Our findings also underline the importance of ensuring high quality surroundings in the departments.

The study has some limitations. The prerequisite for assuming that a 14 item version of the mammography questionnaire could be used to measure satisfaction with mammography in the future is that the respondents answer this version in the same manner as when the questions are incorporated in the 27 item version.

To reduce memory bias and to obtain episode specific responses, both questionnaires were completed in the department. This may have affected the response style towards a social desirability bias, despite anonymity. ${ }^{46}$ The cut off point between satisfied and less satisfied patients was arbitrary, but a comparison with other studies seems to justify the demarcation. ${ }^{31}$

THE FUTURE

We have conducted a study of 11 Norwegian mammography departments, and have used the results to define reference standards for patient satisfaction with mammography. We aim to publish the results in the near future.

\section{Conclusions}

Women's satisfaction with practices differed in different mammography departments for pain and embarrassment associated with the breast compression, information received, perceived punctuality, or quality of the surroundings. This indicated potential for improving either technicians' competence, staff behaviour, or quality of the facilities. Some of women's expectations and attitudes were confirmed as independent predictors of low level of satisfaction.

We thank Professor Petter Laake for statistical advice. This work was supported by the Norwegian Medical Association's Quality Assurance Fund. 1 Orton M, Fitzpatrick R, Fuller A, et al. Factors affecting
women's response to an invitation to attend for a second
breast cancer screening examination. Br f Gen Pract
1991;41:320-3.
2 Vaile MSB, Calnan M, Rutter DR, et al. Breast cancer
screening services in three areas: uptake and satisfaction. $\mathcal{F}$
Public Health Med 1993;15:37-45.
3 Elkind A, Eardley A. Consumer satisfaction with breast
screening: a pilot study. F Public Health Med 1990;12:15-8.
4 Eardley A, Elkind A. A pilot study of attendance for breast
cancer screening. Soc Sci Med 1990;30:693-9.
5 Nielsen B, Miaskowski C, McCoy C, et al. The development
and implementation of standards of care in a breast cancer
screening program. Oncol Nurs Forum 1991;18:67-72. 
6 Cockburn J, Hill D, Irwig L, et al. Development and validation of an instrument to measure satisfaction of participants at breast screening programmes. Eur $\mathcal{F}$ Cancer 1991;

7 Cockburn J, De Luise T, Hurley S, et al. Development and validation of the PCQ: a questionnaire to measure the psychological consequences of screening mammography. Soc Sci Med 1992;34:1129-34.

8 Keefe FJ, Hauck ER, Egert J, et al. Mammography pain and discomfort: a cognitive-behavioral perspective. Pain 1994; 56:247-60.

9 Kopans DB. Breast imaging and the standard of care for the symptomatic patient. Radiology 1993;187:608-11.

10 Linver MN, Osuch JR, Brenner J, et al. The mammography audit: a primer for the Mammography Quality Standards Act (MQSA). AfR Am f Roentgenol 1995;165:19-25.

11 Dodd GD. Mammography quality assurance programs. Cancer 1994;74:239-43.

12 Carey RG, Seibert JH. A patient survey system to measure quality improvement: questionnaire reliability and validity.

13 Fitzpatrick R. Surveys of patient satisfaction: I-Important general considerations. BMF 1991;302:887-9.

14 Fitzpatrick R. Surveys of patient satisfaction: II-Designing a questionnaire and conducting a survey. BMF 1991;302: 1129-32.

15 Lewis JR. Patient views on quality care in general practice: literature review. Soc Sci Med 1994;39:655-70.

16 Rutter DR, Calnan M, Vaile MSB, et al. Discomfort and pain during mammography: description, prediction, and prevention. BMF 1992;305:443-5.

17 Baines CJ, To T, Wall C. Women's attitudes to screening after participation in the National breast screening study. A questionnaire survey. Cancer 1990;65:1663-9.

18 Fallowfield LJ, Rodway A, Baum M. What are the psychological factors influencing attendance, nonattendance, and re-attendance at a breast screening centre? fR Soc Med 1990;83:547-51.

19 Fine MK, Rimer BK, Watts P. Women's responses to the mammography experience. f Am Board Fam Pract 1993;6: mammography experience. F Am Board Fam Pract 1993;6:

$546-$

20 Stein JA, Fox SA, Murata PJ. The influence of ethnicity, socioeconomic status, and psychological barriers on use of mammography. F Health Soc Behav 1992;32:101-13.

21 Smith S, Botha JL, Goosey R, et al. Audit of user satisfaction with the Leicestershire breast screening service; women attending for assessment of abnormal mammograms. $\mathcal{F}$ Public Health Med 1991;13:166-71.

22 Loeken K, Steine S, Sandvik L, et al. A new instrument to measure patient satisfaction with mammography. Validity,
reliability, and discriminatory power. Med Care 1997;35: 731-41.

23 Aro AR, Absetz-Ylöstalo P, Eerola T, et al. Pain and discomfort during mammography. Eur F Cancer 1996;32A:1674-

24 Vernon SW, Laville EA, Jackson GL. Participation in breast screening programs: a review. Soc Sci Med 1990;10:110718 .

25 Wareham NJ. External monitoring of quality of health care in the United States. Quality in Health Care 1994;3:97-101. 6 Thoresen SØ, Sager EM. Quality assurance in breast cancer screening. Oslo: The Cancer Registry of Norway, 1996.

27 Streiner DL, Norman GR. Health measurement scales: a practical guide to their development and use. Oxford: Oxford University Press, 1989.

28 Loeken K, Steine S, Sandvik L, et al. A new measure of patient satisfaction with mammography. Validation by factor analytic technique. Fam Pract 1996;13:67-74.

29 Cockburn J, Hill D, De Luise T, et al. Satisfaction of attenders during the establishment of an Australian mammography screening program. Aust f Public Health 1993;17:1038 .

30 Stomper PC, Kopans DB, Sadowsky NL, et al. Is mammography painful? A multicenter patient survey? Arch Intern Med 1988;148:521-4.

31 Hall JA, Dornan MC. Meta-analysis of satisfaction with medical care: description of research domain and analysis medical care: description of research domain and analysis
of overall satisfaction levels. Soc Sci Med 1988;27:637-44.

32 Hjortdahl P, Lærum E. Continuity of care in general practice: effect on patient satisfaction. BMF 1992;304: $1287-90$

33 Kleinbaum DG, Kupper LL, Muller KE. Applied regression analysis and other multivariable methods. California: Duxbury Press, 1988.

34 Sheldon TA. Quality: link with effectiveness. Quality in Health Care 1994;3(suppl):S41-S5

35 Davies AR. Patient defined outcomes. Quality in Health Care 1994;3(suppl):S6-9.

36 Hopkins A, Gabbay J, Neuberger J. Role of users of health care in achieving a quality service. Quality in Health Care 1994;3:203-9.

37 Øvretveit J. Quality health services. BIOSS Research Report. London: Brunel University, 1990.

38 Coles C. Making audit truly educational. Postgrad Med $\mathcal{F}$ 1990;66:S32-6.
39 Morris KJ, Tarico VS, Smith WL, et al. Critical analysis of radiologist-patient interaction. Radiology 1987;163:565-7. 0 Leany BJ, Martin M. Breast pain associated with mammographic compression. Australas Radiol 1992;36:120-3.

41 Nielsen B, Miaskowski C, Dibble SL. Pain with mammography: fact or fiction? Oncol Nurs Forum 1993;20: 639-42.

42 Ward SE, Gordon D. Application of the American Pain Society quality assurance standards. Pain 1994;56:299306.

43 Kornguth PJ, Rimer BK, Conaway MR, et al. Impact of patient-controlled compression on the mammography experience. Radiology 1993;186:99-102.

44 Fox SA, Klos DS, Worthen NJ, et al. Improving the adherence of urban women to mammography guidelines: strategies for radiologists. Radiology 19;174:203-7.

45 Roworth MA, Mcllwaine GM, Wallace AM. Women's views on the Scottish breast screening programme: a national on the Scottish breast screening programme: a national
consumer opinion survey. Public Health 1993;107:185-92.

46 Ware JE. Effects of acquiescent response set on patient satisfaction ratings. Med Care 1978;16:327-36.

\section{Appendix: The 14 items and six scales of the mammography questionnaire. Scales confirmed and compressed by factor analysis}

SCALE 1 PHYSICAL PAIN

Q 12 Did you find the examination painful? Q 22 Did the examination cause discomfort?

Q 23 I do not dread another identical examination.

SCALE 2 PSYCHOLOGICAL DISTRESS

Q 8 The examination situation made me feel awkward.

Q 4 The examination made me feel embarrassed.

Q 27 Certain things should have been done in other ways.

SCALE 3 STAFFS; PUNCTUALITY

Q 19 I sat too long in the waiting room before being examined.

Q 20 How long did you have to wait before being examined?

SCALE 4 INFORMATION ABOUT THE EXAMINATION

Q 7 The staff told me all I wanted to know. Q 3 I felt free to ask about anything and everything.

Q 11 The staff did not explain what was to be done to me.

SCALE 5 PHYSICAL SURROUNDINGS

Q 16 The examination room was unpleasant.

Q 18 The waiting room was pleasant.

SCALE 6 TECHNICAL SKILLS OF STAFF

Q 5 The examiner seemed to be professionally capable.

$\mathrm{Q}=$ question numbers in the 27 item mammography questionnaire. 